\title{
Links between viruses and prokaryotes throughout the water column along a North Atlantic latitudinal transect
}

\author{
Daniele De Corte ${ }^{1,2}$, Eva Sintes ${ }^{3}$, Taichi Yokokawa ${ }^{1,3,4}$, Thomas Reinthaler ${ }^{3}$ and \\ Gerhard J Herndl ${ }^{1,3}$ \\ ${ }^{1}$ Department of Biological Oceanography, Royal Netherlands Institute for Sea Research (NIOZ), Den Burg, \\ The Netherlands; ${ }^{2}$ Center for Ecological and Evolutionary Studies, University of Groningen, Groningen, \\ The Netherlands and ${ }^{3}$ Department Marine Biology, Faculty Center of Ecology, University of Vienna, \\ Vienna, Austria
}

\begin{abstract}
Viruses are an abundant, diverse and dynamic component of marine ecosystems and have a key role in the biogeochemical processes of the ocean by controlling prokaryotic and phytoplankton abundance and diversity. However, most of the studies on virus-prokaryote interactions in marine environments have been performed in nearshore waters. To assess potential variations in the relation between viruses and prokaryotes in different oceanographic provinces, we determined viral and prokaryotic abundance and production throughout the water column along a latitudinal transect in the North Atlantic. Depth-related trends in prokaryotic and viral abundance (both decreasing by one order of magnitude from epi- to abyssopelagic waters), and prokaryotic production (decreasing by three orders of magnitude) were observed along the latitudinal transect. The virus-to-prokaryote ratio (VPR) increased from $\sim 19$ in epipelagic to $\sim 53$ in the bathy- and abyssopelagic waters. Although the lytic viral production decreased significantly with depth, the lysogenic viral production did not vary with depth. In bathypelagic waters, pronounced differences in prokaryotic and viral abundance were found among different oceanic provinces with lower leucine incorporation rates and higher VPRs in the North Atlantic Gyre province than in the provinces further north and south. The percentage of lysogeny increased from subpolar regions toward the more oligotrophic lower latitudes. Based on the observed trends over this latitudinal transect, we conclude that the viralhost interactions significantly change among different oceanic provinces in response to changes in the biotic and abiotic variables.
\end{abstract}

The ISME Journal (2012) 6, 1566-1577; doi:10.1038/ismej.2011.214; published online 19 January 2012

Subject Category: microbial ecology and functional diversity of natural habitats

Keywords: virus-like particles; prokaryotes; bacteria; North Atlantic Ocean; flow cytometry; DISTML

\section{Introduction}

Viruses are abundant, diverse and dynamic components in marine ecosystems (Sano et al., 2004; Angly et al., 2006; Parada et al., 2007; De Corte et al., 2010). Viral lysis is a key factor in the biogeochemical cycles as it leads to the release of intracellular material from the host cells, stimulating dissolved organic matter cycling (Middelboe and Lyck, 2002; Middelboe et al., 2003; Middelboe and Jørgensen, 2006). Moreover, viruses control prokaryotic and phytoplankton mortality and might help maintaining microbial diversity (Bratbak et al., 1993;

Correspondence: GJ Herndl, Department Marine Biology, Faculty Center of Ecology, University of Vienna, Althanstrasse 14, Vienna 1090, Austria.

E-mail: gerhard.herndl@univie.ac.at

${ }^{4}$ Current address: Center for Marine Environmental Studies (CMES), Ehime University, Bunkyo 3, Ehime 790-8577, Japan.

Received 18 August 2011; revised 13 December 2011; accepted 14 December 2011; published online 19 January 2012
Thingstad and Lignell, 1997; Winter et al., 2005; Breitbart et al., 2008).

There are two main viral life strategies, the lysogenic and the lytic cycle (Weinbauer et al., 2003). The prevalence of one over the other depends on the environmental conditions. Lysogeny is considered an adaptation to oligotrophic conditions, with low host abundance and activity (Weinbauer and Suttle, 1999; Williamson et al., 2002), while the lytic cycle is considered to be dominant in highly productive regions (Weinbauer et al., 2003). Changing trophic conditions lead to changes in the prokaryotic community composition and consequently, to altered virus-host interactions (Weinbauer et al., 1993).

Several studies have examined the prokaryotic (Bacteria and Archaea) abundance and diversity along large-scale oceanographic gradients (Pommier et al., 2007; Varela et al., 2008; Schattenhofer et al., 2009). In contrast, very little information is available on global patterns of viral abundance across different 
oceanic regions. Also, the biogeographic distribution of viral diversity is largely unknown. Until now, only one study, using a metagenomic approach, investigated the viral diversity over different oceanic provinces (Angly et al., 2006). This study revealed a high global viral diversity with consistent differences among different latitudes (Angly et al., 2006).

Although several variables might influence the distribution of viruses on the micro- to large-scale, the availability of suitable hosts is ultimately the crucial factor controlling viral proliferation. Thus, the variability within viral communities should be highly related to changes in host metabolic abundance, activity and diversity. All of these prokaryotic parameters, in turn, depend on abiotic and biotic variables such as nutrient availability and grazing pressure (Middelboe, 2000).

The aim of this study was to investigate the main factors controlling viral abundance, production and the distribution of different viral sub-populations, as revealed by flow cytometry, along a latitudinal transect over four North Atlantic oceanic provinces throughout the entire water column ranging from the epi- to the abyssopelagic layers. The virus-prokaryote interactions, the viral life strategies and the host specificity of viruses might be fundamentally different between different oceanographic provinces and depth layers as are the overall trophic conditions. We used the distance-based multivariate analysis for a linear model using forward selection (DISTLM forward) to identify the best set of environmental parameters explaining the variations in viral abundance, production and contribution of different viral sub-populations to the viral communities in four oceanic provinces of the North Atlantic.

\section{Materials and methods}

\section{Study area and sampling}

Water samples were obtained from 24 depth layers at 33 stations during the research cruises GEOTRACES-1 and -2 (April-July 2010) in the North Atlantic with R/V Pelagia (Figure 1) from five different pelagic zones: upper epipelagic $(10-75 \mathrm{~m})$, lower epipelagic $(75-200 \mathrm{~m})$, mesopelagic (200$1000 \mathrm{~m})$, upper bathypelagic (1000-2500 m), subsequently termed bathypelagic, and the layer between 2500 and $6000 \mathrm{~m}$ (thus, lower bathypelagic plus abyssopelagic) indicated below by the term 'abyssopelagic' for the sake of clarity. The samples were collected in four different oceanic provinces based on the classification scheme of ecological regions in the ocean (Longhurst, 1998). Samples were taken in the North Atlantic Arctic province (ARCT; $70^{\circ} \mathrm{N}-$ $55^{\circ} \mathrm{N}$ ), the North Atlantic Drift province (NADR; $55^{\circ} \mathrm{N}-40^{\circ} \mathrm{N}$ ), the North Atlantic Gyral province (NAG) comprising the North Atlantic Tropical and Subtropical Gyral province $\left(40^{\circ} \mathrm{N}-12^{\circ} \mathrm{N}\right)$, and the Western Tropical Atlantic (WTRA; $12^{\circ} \mathrm{N}-12^{\circ} \mathrm{S}$ ) province (Figure 1). Sampling was performed with a

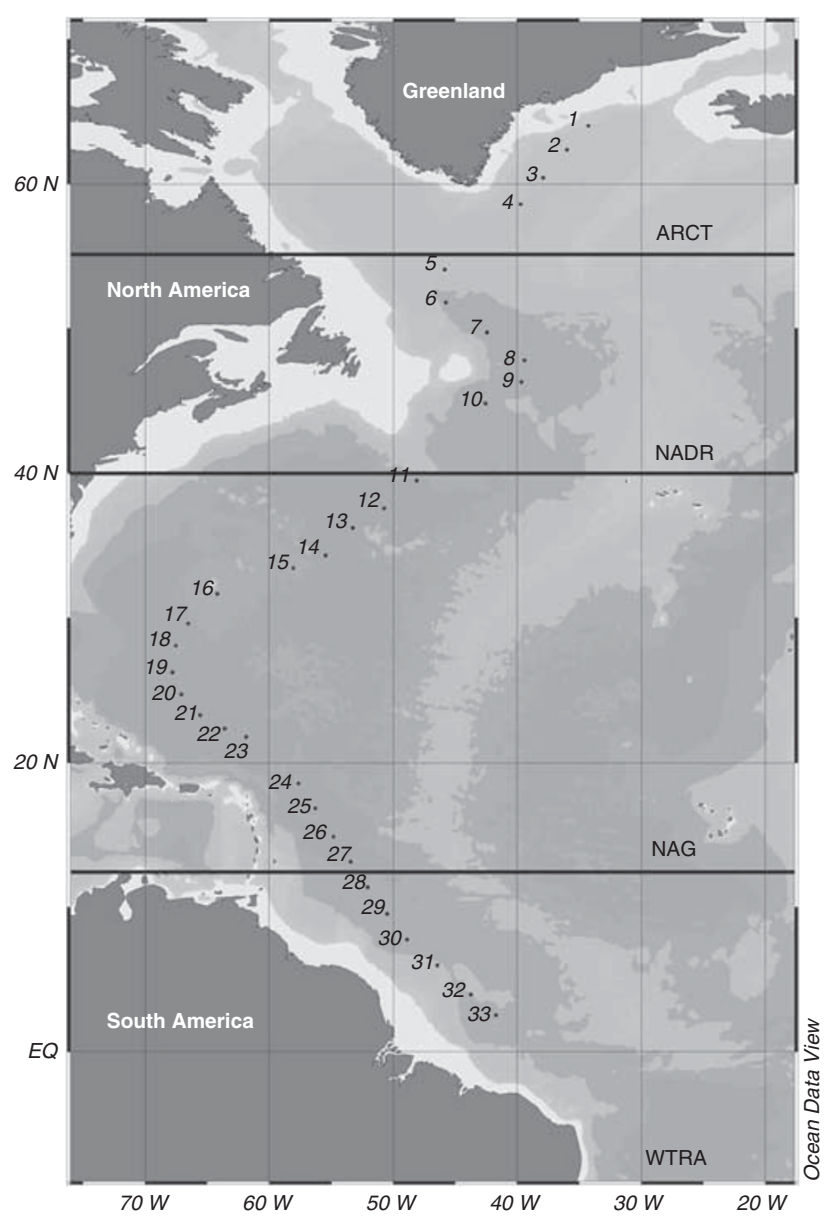

Figure 1 Cruise track and sampling stations (indicated by dots) occupied during the GEOTRACES research expeditions-1 and -2 between April and July 2010 . ARCT $\left(70^{\circ} \mathrm{N}-55^{\circ} \mathrm{N}\right)$, NADR $\left(55^{\circ} \mathrm{N}-\right.$ $\left.40^{\circ} \mathrm{N}\right)$, NAG $\left(40^{\circ} \mathrm{N}-12^{\circ} \mathrm{N}\right)$, WTRA $\left(12^{\circ} \mathrm{N}-12^{\circ} \mathrm{S}\right)$. Bold horizontal lines denote borders between oceanic provinces following the description given in Longhurst (1998).

CTD (conductivity-temperature-depth; Seabird, Bellevue, WA, USA) rosette sampler equipped with 24 25-l Niskin bottles and sensors for chlorophyll fluorescence, turbidity, photosynthetic active radiation and oxygen. The apparent oxygen utilization was calculated in Ocean Data View (ODV version 4.3.7, Schlitzer, 2002) as the difference between the $\mathrm{O}_{2}$ saturation at a given temperature and salinity and the actual $\mathrm{O}_{2}$ concentration measured at this station and depth (Pytkowicz, 1971).

\section{Prokaryotic and viral abundance}

Samples for prokaryotic and viral abundance were collected at all the 33 stations and at all 24 depth layers at each station. Flow cytometric enumeration of viruses and prokaryotes was used as a fast and reliable method resulting in similar viral and prokaryotic abundances as determined by epifluorescence microscopy (Del Giorgio et al., 1996; Marie et al., 1999; Brussaard, 2004).

The prokaryotic abundance was determined using standard procedures (Del Giorgio et al., 1996; 
Brussaard, 2004) with modification. Briefly, $2 \mathrm{ml}$ samples were fixed with glutaraldehyde $(0.5 \%$ final concentration), shock-frozen in liquid $\mathrm{N}_{2}$ and kept at $-80{ }^{\circ} \mathrm{C}$ until analysis. Samples were thawed to room temperature and $0.5 \mathrm{ml}$ subsamples stained with SYBR Green I (Molecular Probes, Invitrogen, Carlsbad, CA, USA) in the dark for $10 \mathrm{~min}$. The prokaryotes were enumerated on a FACSAria II flow cytometer (Becton Dickinson, Franklin Lakes, NJ, USA) by their signature in a plot of green fluorescence versus side scatter.

Viral abundance was measured by flow cytometry after SYBR Green I staining (Brussaard, 2004). Briefly, $2 \mathrm{ml}$ samples were fixed with glutaraldehyde (0.5\% final concentration), held at $4{ }^{\circ} \mathrm{C}$ for $10-30 \mathrm{~min}$, frozen in liquid $\mathrm{N}_{2}$ and subsequently, stored at $-80{ }^{\circ} \mathrm{C}$ until analysis. Before analysis, samples were thawed and $0.5 \mathrm{ml}$ subsamples stained in the dark with SYBR Green I (Molecular Probes) at a final concentration of $0.5 \times$ of the manufacturer's stock solution at $80{ }^{\circ} \mathrm{C}$ for $10 \mathrm{~min}$. Viruses were enumerated on a FACSAria II flow cytometer (Becton Dickinson) as described above for prokaryotic abundance.

Depending on their respective signature in the cytogram of green fluorescence versus side scatter, two different prokaryotic populations (high and low nucleic acid content prokaryotes) and three different viral populations (high-, medium- and low-fluorescence viruses) were discriminated (Supplementary Figure S1).

Leucine incorporation into heterotrophic prokaryotes as a measure of prokaryotic production

Samples to measure leucine incorporation into heterotrophic prokaryotes were collected at 27 stations at seven selected depths distributed over the five oceanic provinces described above. Additionally, leucine incorporation rates were determined at all the sampled 24 depth layers at five stations (Sts 5, 8, 14, 20 and 33). Triplicate subsamples $(1.5 \mathrm{ml})$ and one trichloroacetic acid (TCA) killed blank were dispensed into screwcapped centrifuge vials (Scientific System Inc., VWR, Radnor, PA, USA, $2.0 \mathrm{ml}$ screw tube), amended with $5 \mathrm{nmol}^{-1}$ (final concentration) of $\left[{ }^{3} \mathrm{H}\right]$-leucine (product \#: ART 0840, American Radiolabeled Chemicals Inc., St Louis, MO, USA) and incubated at in situ temperature $\left( \pm 1^{\circ} \mathrm{C}\right)$ in the dark for $1 \mathrm{~h}$ (samples from 0 to $200 \mathrm{~m}$ depth) or for $24 \mathrm{~h}$ (samples from 250 to $6000 \mathrm{~m}$ ) following the protocol of Smith and Azam (1992). A concentration of $5 \mathrm{nmoll}^{-1}$ final concentration of $\left[{ }^{3} \mathrm{H}\right]$-leucine additions resulted in heterotrophic prokaryotic production estimates not significantly different from $10 \mathrm{nmol} \mathrm{l}^{-1}\left[{ }^{3} \mathrm{H}\right]$-leucine additions hence, $5 \mathrm{nmol} \mathrm{l}^{-1}$ $\left[{ }^{3} \mathrm{H}\right]$-leucine additions were considered as saturating concentrations for prokaryotic production measurements (data not shown). The incubations were terminated by adding TCA (final concentration $5 \%$ ). Thereafter, the samples were centrifuged at
$18000 \mathrm{~g}$ for $10 \mathrm{~min}$ and the supernatant siphoned off. The pellet was resuspended in TCA (5\%), centrifuged again for $10 \mathrm{~min}$ and the TCA discarded and finally, an ethanol rinse (80\%, ice-cold) was applied. One ml of Ultima-GOLD (Perkin Elmer, Waltham, MA, USA) scintillation cocktail was added to the pellet after siphoning off the ethanol. The radioactivity was measured in a liquid scintillation counter (Tri-Carb 3100TR, Perkin Elmer). Quenching was corrected using an external standard channel ratio. The disintegrations per minute of the TCAkilled blank were subtracted from the average disintegrations per minute of the samples, and the resulting disintegrations per minute converted to leucine incorporation rates. The cell-specific leucine incorporation rate was calculated by dividing the bulk leucine incorporation rates by the prokaryotic abundance (Kirchman, 2002).

\section{Viral production}

Viral (lytic and lysogenic) production was measured by the dilution approach (Wilhelm et al., 2002) covering the different oceanic provinces and depth layers (Table 1). Lytic and lysogenic viral productions (VPs) were determined at 18 samples originating from eight stations. Per sample, $50 \mathrm{ml}$ of the prokaryotic concentrate obtained by $0.2 \mu \mathrm{m}$ tangential-flow filtration (Vivascience, Sartorius Stedim Biotech, Aubagne Cedex, France) was added to $450 \mathrm{ml}$ of virus-free filtrate produced from the same water sample using a $30 \mathrm{kDa}$ molecular weight cutoff tangential-flow filtration (Vivascience). This approach resulted in a prokaryotic abundance similar to in situ abundance. The experiments were performed in triplicate at in situ temperature in the dark with and without the addition of mitomycin C (final concentration $1 \mu \mathrm{g} \mathrm{ml}^{-1}$; SIGMA, St Louis, MO, USA) (Ortmann et al., 2002). Mitomycin C was added to induce the lytic cycle of lysogenic viruses. Subsamples were taken to enumerate prokaryotes and viruses at 4- to 6-h intervals over a time span of $72 \mathrm{~h}$. VP was calculated as the slope of a first order regression line of viral abundance versus incubation time for the samples showing a single peak in viral abundance (Wilhelm et al., 2002).

The lytic VP was obtained from incubations without mitomycin C added. Lysogenic VP represents the difference between the VP obtained in the mitomycin C-treated samples and the VP in the treatments without mitomycin C.

Estimation of other variables measured during the VP experiments

Net prokaryotic production (NPP) was determined from the changes in cell abundance over the sampling period using the formula:

$$
\mathrm{NPP}=\left(\frac{P_{1}-P_{0}}{T_{1}-T_{0}}\right)
$$


where $P_{1}$ and $P_{0}=$ prokaryotic abundance at the end and the beginning of the experiment, respectively, $T_{1}-T_{0}=$ time difference in days between the end and the beginning of the experiment, that is, the duration of the experiment (Ortmann et al., 2002).

Prokaryotic turnover time (PTT) was calculated using the formula from Parada et al. (2008):

$$
\mathrm{PTT}=\frac{1}{\left(\frac{\mathrm{NPP}}{P_{0}}\right)}
$$

Viral turnover time (VTT) was calculated using the formula:

$$
\mathrm{VTT}=\frac{1}{\left(\frac{\mathrm{vP}}{V_{0}}\right)}
$$

where VP is the VP and $V_{0}$ is the viral abundance at the beginning of the experiment (Parada et al., 2008; De Corte et al., 2010).

\section{Statistical analysis}

Spearman rank correlation was performed to analyze the relations between several measured parameters. Regression analysis was used to predict the relationship between the log transformed viral and prokaryotic abundance and production versus temperature and depth (independent variables). Analysis of variance (ANOVA on rank) was performed to test possible differences among depth layers and, if significant differences were observed, the post hoc Dunn's test was also performed.

The distance-based multivariate analysis for a linear model using forward selection (DISTLM forward) was applied to test the relationships between viral abundance and biotic and abiotic environmental parameters (Anderson et al., 2004).

\section{Results}

Physical and chemical variables of the water column The physical characteristics and the apparent oxygen utilization of the different depth layers of the oceanic provinces sampled are given in Supplementary Table S1. Temperature significantly decreased over the entire transect from the epipelagic (mean \pm s.d.: $20.2 \pm 8.2^{\circ} \mathrm{C}$ ) to the abyssopelagic layer $\left(2.2 \pm 0.2{ }^{\circ} \mathrm{C}\right.$; ANOVA on rank, $P<0.001$, post hoc Dunno's test, $P<0.05)$. The highest temperature in the epipelagic layers was measured in the WTRA $\left(28.3 \pm 0.7^{\circ} \mathrm{C}\right)$ followed by the NAG $\left(24.2 \pm 4.1^{\circ} \mathrm{C}\right)$, NADR $\left(11.8 \pm 3.6^{\circ} \mathrm{C}\right)$ and ARCT $\left(5.7 \pm 0.7^{\circ} \mathrm{C}\right)$. The highest temperature in the lower epi- and mesopelagic waters was found in the NAG $\left(20.9 \pm 3.2{ }^{\circ} \mathrm{C}\right)$. The temperature in the bathy- and abyssopelagic layers did not reveal pronounced latitudinal variations, albeit in the ARCT, the temperature was slightly lower than in the other provinces (Supplementary Table S1).

The salinity significantly decreased from the lower epi- to the abyssopelagic layers in all the 
provinces (ANOVA on rank $P<0.001$, post hoc Dunno's test $P<0.05$ ). The lowest salinity was found in the ARCT province whereas the highest salinity was found in the NAG zone (Supplementary Table S1). Salinity was not significantly different in the bathy- and abyssopelagic layer over the latitudinal transect (Supplementary Table S1).

The apparent oxygen utilization significantly decreased in the upper epipelagic layer from the ARCT $\left(43.49 \pm 4.38 \mu \mathrm{mol} \mathrm{O}_{2} \mathrm{~kg}^{-1}\right)$ to the WTRA $\left(21.44 \pm 3.61 \mu \mathrm{mol} \mathrm{O} \mathrm{kg}^{-1}\right.$; ANOVA on rank, $P<0.001$, post hoc Dunno's test, $P<0.05)$. Moreover, the apparent oxygen utilization significantly increased with depth from the epi- to the meso- (NADR, WTRA) or bathypelagic layers (ARCT, NAG) (ANOVA on rank, $P<0.001$ ) (Supplementary Table S1).

\section{Prokaryotic and viral abundance}

The prokaryotic abundance significantly decreased with depth from an average over all the stations of $2.5 \pm 1.1 \times 10^{5} \mathrm{cells} \mathrm{ml}^{-1}$ in the epipelagic waters to $0.1 \pm 0.05 \times 10^{5} \mathrm{cells} \mathrm{ml}^{-1}$ in the abyssopelagic waters (ANOVA on rank, $P<0.001$, post hoc Dunno's test, $P<0.05$ ) (Supplementary Table S2, Figure 2a). Regardless of the depth horizon, highest prokaryotic abundance was found in the ARCT, while the lowest abundance was found in the NAG and WTRA (Figure 2a). Prokaryotic abundance was negatively related to depth (linear regression $\left.r^{2}=0.80, P<0.001\right)$ and positively related to temperature (linear regression $r^{2}=0.52, P<0.001$ ), viral abundance (Spearman's rank correlation, $r^{2}=0.90$, $P<0.001)$ and prokaryotic heterotrophic production
(Spearman's rank correlation, $r^{2}=0.92, P<0.001$ ) (Figures 3a, b, 4a and b).

The abundance of viruses significantly decreased with depth from an average over all the stations of $4.48 \pm 2.38 \times 10^{6}$ viruses $\mathrm{ml}^{-1}$ and $0.58 \pm 0.23 \times 10^{6}$ viruses $\mathrm{ml}^{-1}$ in the epi- and abyssopelagic waters, respectively (Supplementary Table S2) (ANOVA on rank, $P<0.001$ ). The viral abundance did not change significantly between the bathy- and the abyssopelagic waters (ANOVA on rank, $P=0.460$ ). Generally, viral abundance was negatively related with depth (linear regression $r^{2}=0.71, P<0.001$ ) and positively correlated with temperature (linear regression $r^{2}=0.51, P<0.001$ ), prokaryotic abundance (Spearman's rank correlation, $\left.r^{2}=0.90, P<0.001\right)$ and heterotrophic production (Spearman's rank correlation, $r^{2}=0.86, P<0.001$ ) (Figures 3a, b, 4a and b). In the epipelagic layer, highest viral abundance was found in the WTRA whereas the lowest abundance was measured in the ARCT (ANOVA on rank, $P<0.001$, post hoc Dunno's test, $P<0.05$ ). In the meso, bathy- and abyssopelagic layers, the viral abundance decreased from the ARCT to the WTRA (ANOVA on rank, $P<0.001$ ).

High and low nucleic acid content prokaryotic populations were distinguished based on their signature of SYBR Green fluorescence versus side scatter, as determined by flow cytometry (Supplementary Figure S1a). The fraction of the prokaryotic community with high nucleic acid content did not show any significant trend neither with depth nor with latitude (Supplementary Table S2).

Three different viral populations were distinguished based on their fluorescence signal determined
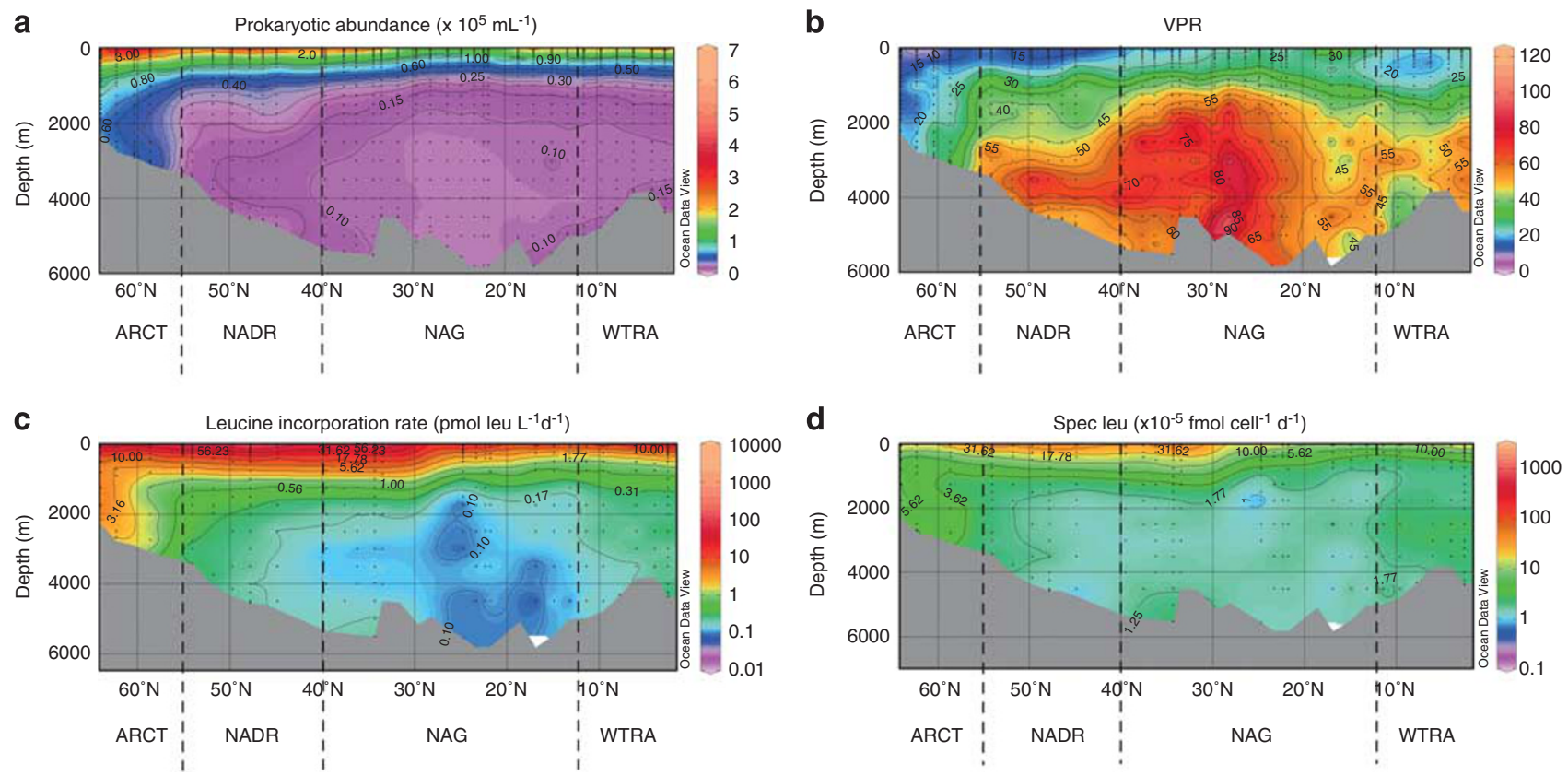

Figure 2 Biotic parameters measured along the North Atlantic latitudinal transect in the epi- meso-, bathy- and abyssopelagic layers: (a) prokaryotic abundance, (b) VPR, (c) heterotrophic prokaryotic production measured via leucine incorporation and (d) cell-specific leucine incorporation rate. Broken vertical lines denote borders between oceanic provinces following the description given in Longhurst (1998). For abbreviations of the oceanic provinces see Figure 1. 

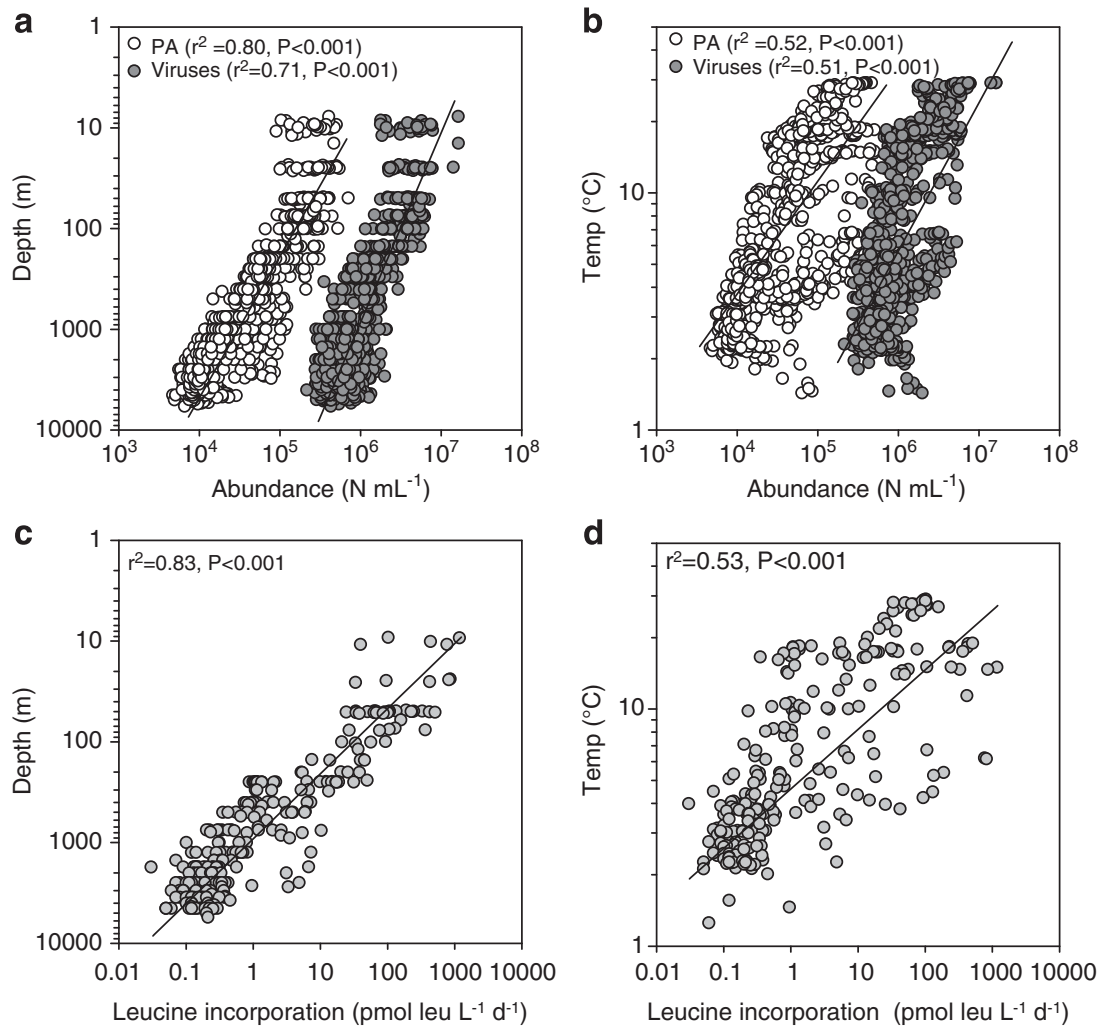

Figure 3 Relation between prokaryotic abundance (PA) and viruses versus (a) depth and (b) temperature, leucine incorporation versus (c) depth and (d) temperature.
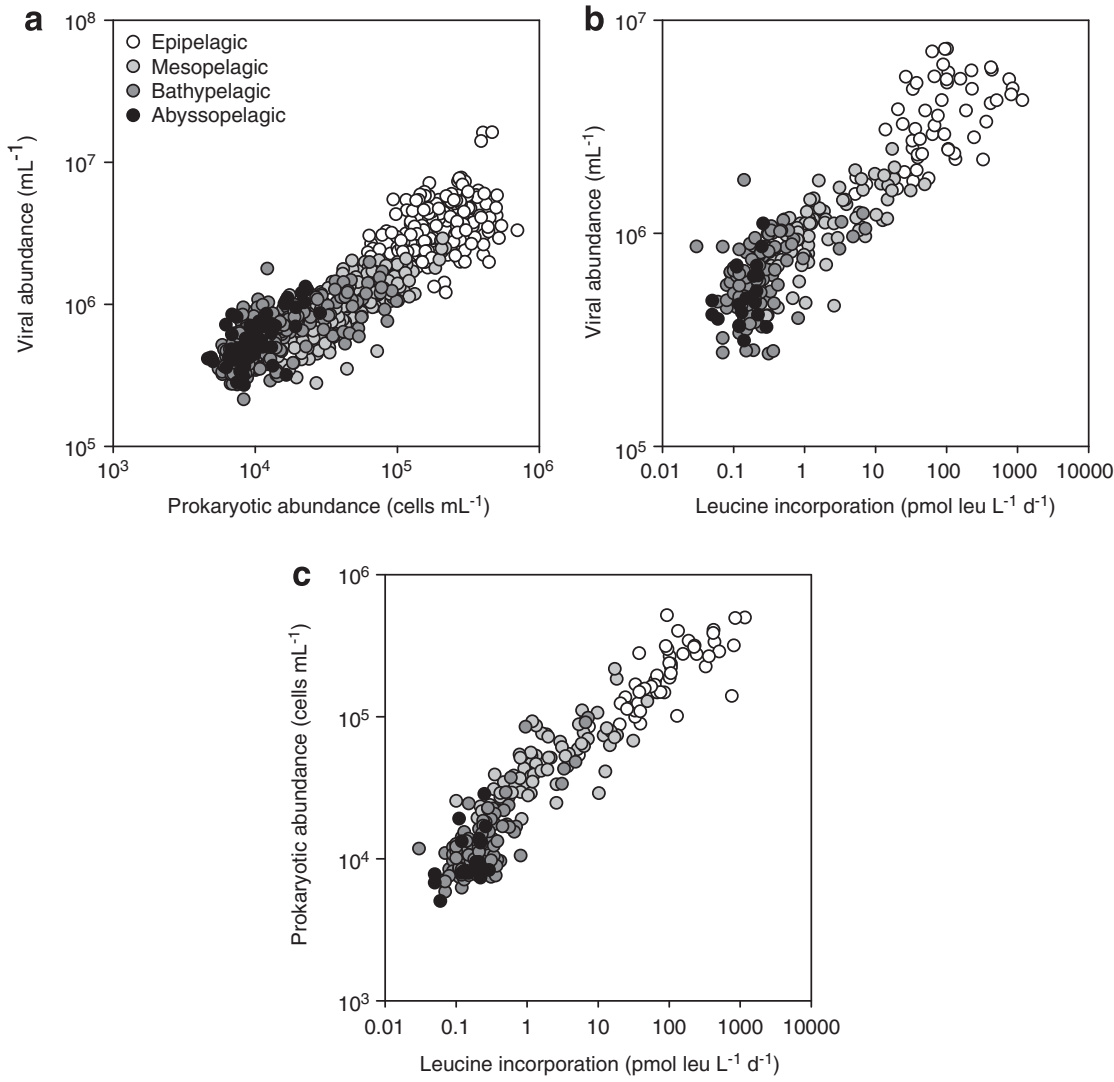

Figure 4 Relation between viral abundance versus (a) prokaryotic abundance and (b) leucine incorporation rate and (c) relation between prokaryotic abundance (PA) versus leucine incorporation rate. 
by flow cytometry (Supplementary Figure S1b). The abundance of the three viral populations decreased with depth (ANOVA on rank, $P<0.001$ ). However, only the percentage of the high-fluorescence viral population correlated with depth (Spearman's rank correlation coefficient $r_{s}=-0.531, P<0.001$ ), ranging, on average, from $22 \%$ in the epipelagic waters to $8 \%$ of the total viral abundance in the abyssopelagic zone (Supplementary Table S2). The mediumfluorescence population comprised, on average, $70 \%$ of total viral abundance without any significant trend with depth. The low-fluorescence viral population showed the highest variability among the three viral populations ranging, on average, from $10 \%$ to $27 \%$, again without a specific depth-related trend (Supplementary Table S2). No significant latitudinal differences over specific depth horizons were found for the three viral populations.

The virus-to-prokaryote ratio (VPR) significantly increased with depth from an average over all the stations of $19.2 \pm 8.3$ in the epipelagic layer to $59.1 \pm 18.7$ (ANOVA on rank, $P<0.001$ ) in the abyssopelagic layer (Supplementary Table S2, Figure 2b). Although the VPR was positively related with depth (linear regression $r^{2}=0.50, P<0.001$ ), it was negatively correlated with the prokaryotic production (Spearman's rank correlation coefficient, $\left.r_{s}=-0.75, P<0.001\right)$. In the bathypelagic and abyssopelagic waters of the NAG, the VPR was significantly higher than in the ARCT and WTRA provinces (ANOVA on ranks, $P<0.001$, post hoc Dunno's test, $P<0.05)$ (Supplementary Table S2, Figure 2b).

Leucine incorporation as a proxy of heterotrophic prokaryotic production

Leucine incorporation into heterotrophic prokaryotes exponentially decreased from the surface to abyssopelagic waters by three orders of magnitude from an average over the entire transect of $227.4 \pm 268.1$ to $0.17 \pm 0.09$ pmol leu $\mathrm{l}^{-1}$ day $^{-1}$ (Supplementary Table S2, Figures 2c and 3c). Significant differences in leucine incorporation were also found between the bathy- and abyssopelagic layer (ANOVA on ranks, $P<0.001$, post hoc Dunno's test, $P<0.05$ ). Leucine incorporation was positively related with temperature (linear regression, $r^{2}=0.53, P<0.001$ ), and viral and prokaryotic abundance (Figures $3 \mathrm{~d}, 4 \mathrm{~b}$ and c). In the bathy- and abyssopelagic waters of the NAG, leucine incorporation was significantly lower (ANOVA on ranks, $P<0.001$, post hoc Dunno's test, $P<0.05)$ than in the bathy- and abyssopelagic waters of the ARCT, NADR and WTRA regions (Supplementary Table S2, Figure 2c).

Cell-specific leucine incorporation decreased with depth from an average over all the stations of $85.2 \pm 95.5 \times 10^{-5} \mathrm{fmol}^{-1} \mathrm{eu} \mathrm{cell}^{-1} \mathrm{day}^{-1}$ to $1.6 \pm 0.7 \times$ $10^{-5} \mathrm{fmol}$ leu cell ${ }^{-1} \mathrm{day}^{-1}$. The highest cell-specific activity was found in the NADR province in the epiand mesopelagic layers whereas in the bathypelagic zone, the highest cell-specific leucine incorporation

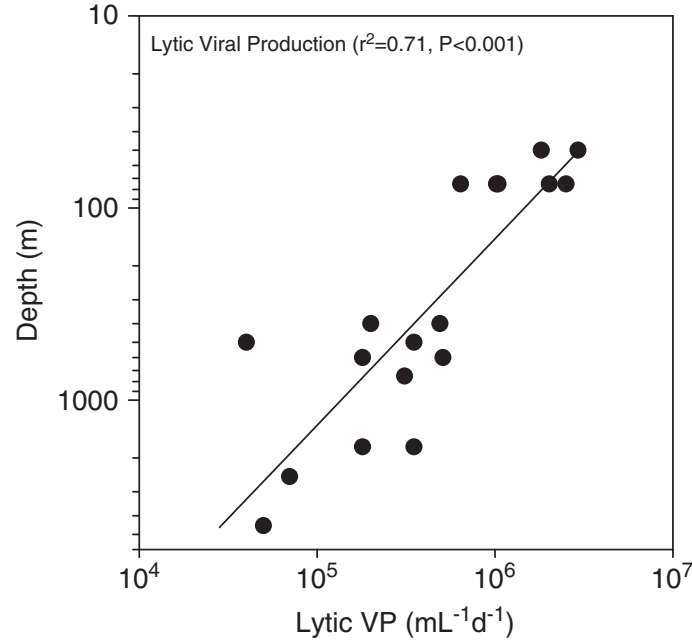

Figure 5 Relation between lytic VP versus depth.

was detected in the ARCT region (Supplementary Table S2, Figure 2d). In the bathy- and abyssopelagic waters of the NAG, cell-specific leucine incorporation rates were lower than in the ARCT province (ANOVA on ranks, $P=0.002$, post hoc Dunno's test, $P<0.05)$ (Figure 2d).

\section{Viral production}

Lytic VP decreased by one order of magnitude from $29.3 \times 10^{5} \mathrm{ml}^{-1} \mathrm{day}^{-1}$ in the epipelagic layers to $0.5 \times 10^{5} \mathrm{ml}^{-1} \mathrm{day}^{-1}$ in the bathypelagic realm (Table 1, Figure 5) without differences among the oceanographic provinces. Although the relative contribution of the three viral populations (distinguished by flow cytometry) to the total VP did not change with depth, their contribution changed with latitude (Table 1). The contribution of the high- and mediumfluorescence viral population to total lytic VP was positively correlated with latitude and therefore, increased from the WTRA to the ARCT (Spearman rank's coefficient $r_{s}=0.47, P=0.049$ and $r_{s}=0.60$, $P=0.008$, respectively). In contrast, the contribution of the low-fluorescence viral population to total lytic VP was negatively correlated with latitude (Spearman rank's coefficient $r_{s}=-0.60, P=0.007$ ) hence, decreased from the WTRA to the ARCT (Table 1).

The lysogenic VP ranged between $38.3 \times 10^{5}$ and $0.6 \times 10^{5} \mathrm{ml}^{-1} \mathrm{day}^{-1}$, contributing between $17 \%$ and $95 \%$ (on average $68 \pm 26 \%$ ) to total VP (Table 1). Generally, the contribution of lysogeny to total VP was negatively related to latitude (Spearman rank's coefficient $r_{s}=-0.71, P=0.01$ ), however, no depthrelated trends were discernable.

\section{Other prokaryotic variables derived from VP experiments}

The NPP (production in the presence of viral lysis) was negatively related to latitude (Spearman rank's coefficient $r_{s}=-0.88, P<0.01$; Table 1 ) and positively 
related to temperature (Spearman rank's coefficient $r_{s}=0.77, P=0.001$; Table 1).

The PTT (Table 1) calculated from the NPP measured during the dilution experiments was negatively correlated with temperature and positively with latitude (Spearman rank's coefficient $r_{s}=-0.58, P=0.02, r_{s}=0.86, P<0.01$, respectively; Table 1). Also the PTT based on leucine incorporation rates significantly varied with latitude in the epi- (upper and lower) and mesopelagic layers (Spearman rank's coefficient $r_{s}=-0.45, P<0.01$; $r_{s}=-0.59, P<0.02 ; r_{s}=-0.46, P<0.01$, respectively; data not shown) and for the whole data set with temperature (Spearman rank's coefficient $r_{s}=-0.63$, $P<0.01$; data not shown). Although the two estimates of the PTT showed similar trends with latitude and temperature, the PTT based on the leucine incorporation rate was at least one order of magnitude higher in the NADR and two orders of magnitude higher in the NAG and WTR provinces than the PTT estimated from the increase in cell abundances in the dilution experiments.

The prokaryotic (calculated from the NPP) and VTTs were similar in the NADR, whereas in the NAG and WTRA, the PTT was one order of magnitude lower than the VTT (Table 1). The VTT ranged between 1 and 18 days and was significantly correlated with depth (Spearman rank's coefficient $\left.r_{s}=0.48, P=0.044\right)$.

\section{Relationships between viral and environmental parameters}

The multivariate multiple regression analysis was used to select the best predictor variables explaining the variability of the viral abundance between the different depth layers (Table 2) and between the oceanographic provinces (Table 3).

Considering the whole data set (all depth layers and all stations), the variability of viral abundance was mainly explained by prokaryotic abundance, temperature and latitude, which together accounted for $73 \%$ of the total variation (Table 2). The prokaryotic abundance accounted for $46 \%$ of the variation in viral abundance, while temperature and latitude accounted for $15 \%$ and $11 \%$, respectively (Table 2). The variables explaining most of the variability in viral abundance in the epipelagic zone of the whole transect were prokaryotic production, latitude and temperature, together explaining $56 \%$ of the variation in viral abundance, although the contribution of latitude was low $\left(r^{2}=0.05 ; P=0.04\right)$ (Table 2). In the mesopelagic layer, the main predictor parameters for the variability in viral abundance over the latitudinal transect were prokaryotic abundance, temperature, latitude and the \% high nucleic acid containing prokaryotes (cumulative $r^{2}=0.62$ ), with prokaryotic abundance and latitude explaining 52\% of the variability in viral abundance. Latitude and temperature explained $47 \%$ and $88 \%$ of the variations in viral abundance in the bathy- and abyssopelagic realm, respectively (Table 2).

Potential differences among the oceanic provinces in the parameters explaining the variation in viral abundance were investigated using data collected throughout the water column (Table 3). The prokaryotic abundance accounted for $69 \%, 68 \%$ and $13 \%$ of the variation in viral abundance in the water column of the ARCT, NADR and WTRA, respectively. Temperature accounted for $12 \%, 73 \%$ and $92 \%$ of the variation in viral abundance in the ARCT, NAG and WTRA, respectively (Table 3). Surprisingly, heterotrophic prokaryotic production (estimated via leucine incorporation) explained only $3 \%$ and $1 \%$ of the variation in viral abundance throughout the water column in the NADR and NAG and depth and the \% high nucleic acid only $6 \%$ and $2 \%$, respectively, in the NADR (Table 3). Although the contribution of prokaryotic abundance explaining the variation in viral abundance decreased from

Table 2 Results of the multivariate multiple regression analysis with forward selection (DISTML forward) to explain the variability in viral abundance throughout the water column (total) and in specific depth layers

\begin{tabular}{|c|c|c|c|c|c|}
\hline Depth layer & Selected variables & Pseudo-F & $\mathrm{P}$ & $\mathrm{r}^{2}$ & Cumulative \\
\hline \multirow[t]{3}{*}{ Total $(n=256)$} & Prokaryotic abundance & 217.2 & 0.001 & 0.46 & 0.46 \\
\hline & Temperature & 103.1 & 0.001 & 0.15 & 0.61 \\
\hline & Latitude & 106.2 & 0.001 & 0.11 & 0.73 \\
\hline \multirow[t]{3}{*}{ EPI $(n=53)$} & Prokaryotic production & 27.2 & 0.001 & 0.35 & 0.35 \\
\hline & Temperature & 17.1 & 0.001 & 0.15 & 0.50 \\
\hline & Latitude & 4.4 & 0.043 & 0.05 & 0.56 \\
\hline \multirow[t]{4}{*}{$\operatorname{MESO}(n=83)$} & Prokaryotic abundance & 50.8 & 0.001 & 0.39 & 0.39 \\
\hline & Latitude & 24.5 & 0.001 & 0.13 & 0.52 \\
\hline & Temperature & 11.2 & 0.003 & 0.08 & 0.60 \\
\hline & \%HNA & 3.6 & 0.049 & 0.02 & 0.62 \\
\hline \multirow[t]{2}{*}{ BATHY $(n=102)$} & Latitude & 73.91 & 0.001 & 0.43 & 0.43 \\
\hline & Temperature & 7.45 & 0.012 & 0.04 & 0.47 \\
\hline \multirow[t]{2}{*}{ ABYSSO $(n=18)$} & Latitude & 71.73 & 0.001 & 0.82 & 0.82 \\
\hline & Temperature & 7.47 & 0.019 & 0.06 & 0.88 \\
\hline
\end{tabular}

Abbreviations: ABYSSO, abyssopelagic; BATHY, bathypelagic; EPI, epipelagic; HNA, high nucleic acid; MESO, mesopelagic; $n$, number of samples.

The response variable was log transformed and the resulting data converted into Euclidian distance similarities matrices. The Pseudo-F and the $P$-values were obtained by permutation $(n=999)$. 
Table 3 Results of the multivariate multiple regression analysis with forward selection (DISTML forward) to explain the variability in viral abundance in different geographic regions

\begin{tabular}{|c|c|c|c|c|c|}
\hline Provinces & Selected variables & Pseudo-F & $\mathrm{P}$ & $\mathrm{r}^{2}$ & Cumulative \\
\hline \multirow[t]{2}{*}{$\operatorname{ARCT}(n=20)$} & Prokaryotic abundance & 40.6 & 0.001 & 0.69 & 0.69 \\
\hline & Temperature & 11.5 & 0.003 & 0.12 & 0.82 \\
\hline \multirow[t]{4}{*}{ NADR $(n=61)$} & Prokaryotic abundance & 126.8 & 0.001 & 0.68 & 0.68 \\
\hline & Depth & 14.7 & 0.001 & 0.06 & 0.75 \\
\hline & Prokaryotic production & 7.9 & 0.011 & 0.03 & 0.78 \\
\hline & $\%$ HNA & 4.2 & 0.040 & 0.02 & 0.79 \\
\hline \multirow{3}{*}{ NAG $(n=116)$} & Temperature & 307.3 & 0.001 & 0.73 & 0.73 \\
\hline & Prokaryotic abundance & 102.7 & 0.001 & 0.13 & 0.86 \\
\hline & Prokaryotic production & 3.8 & 0.046 & 0.01 & 0.87 \\
\hline WTRA $(n=55)$ & Temperature & 575.84 & 0.001 & 0.92 & 0.92 \\
\hline
\end{tabular}

Abbreviations: ARCT, North Atlantic Arctic province; HNA, high nucleic acid; NADR, North Atlantic Drift province; NAG, North Atlantic Gyral province; $n$, number of samples; WTRA, Western Tropical Atlantic.

The response variable was log transformed and the resulting data converted in Euclidian distance similarities matrices. The Pseudo-F and the $\mathrm{p}$ value were obtained by permutation $(n=999)$. For physical and chemical characteristics of the oceanic provinces see Supplementary Table S1.

the ARCT to the WTRA, the contribution of the temperature increased from the ARCT to the WTRA (Table 3).

The variability in lytic VP was mainly explained by depth and viral abundance (DISTML test, cumulative $r^{2}=0.82$ ), with depth alone explaining $72 \%$ of the variation (data not shown).

\section{Discussion}

\section{Latitudinal trends in prokaryotic abundance and production}

Overall, the prokaryotic abundance was higher in the ARCT than in the other oceanographic provinces, particularly in the bathypelagic waters (Figure 2a, Supplementary Table S2). In this deepwater layer, prokaryotic abundance decreased from the ARCT toward the NAG and WTRA (Figure 2a), reflecting the distribution pattern of phytoplankton productivity in these Atlantic provinces (Sathyendranath et al., 1995). Similarly to the prokaryotic abundance, the highest heterotrophic prokaryotic production (measured as leucine incorporation) was found in the ARCT and NADR (Supplementary Table S2). The rates and ranges of leucine incorporation determined for the epipelagic layer in this study are in the range of values reported by other North Atlantic studies (Reinthaler et al., 2006). Thus, the variability of the heterotrophic prokaryotic activity in the epipelagic layer reported here (Supplementary Table S2) results from the large biogeographic area covered in this study extending over four oceanographic provinces, all exhibiting specificities in primary production and trophic conditions. Remarkably, there was a pronounced minimum in leucine incorporation detectable in the NAG below about $2000 \mathrm{~m}$ depth (Figure 2c). The NAG province is generally characterized by low primary production in the surface waters and low export flux (Sathyendranath et al., 1995). This low supply of particulate organic matter sedimenting into the deep waters of the NAG apparently provokes the lower prokaryotic abundance and leucine incorporation in the bathy- and abyssopelagic waters in the NAG than at the same depth layers outside the NAG further north and south (Figures 2a and c). This supports the notion that bathy- and abyssopelagic prokaryotic heterotrophic activity mainly depends on sedimenting particulate organic matter supply (Nagata et al., 2000; Baltar et al., 2009) and hence, surface water primary production.

Cell-specific leucine incorporation followed a similar trend as bulk leucine uptake with pronounced differences among the oceanographic provinces particularly in the dark realm of the ocean (Figure 2d). Cell-specific leucine incorporation exponentially decreased with depth by two orders of magnitude with lowest cell-specific activity in the NAG (Figure 2d). A similar increase in deep-water leucine incorporation from the NAG to the WTRA as reported here for the western basin of the North Atlantic has also been shown for the eastern basin of the Atlantic (Baltar et al., 2009). Taken together, the overall prokaryotic activity in the bathy- and abyssopelagic waters appears to be related to the sedimenting particle flux, which, in turn, is related to the overall phytoplankton productivity. The cellspecific leucine incorporation rates measured in the ARCT, NAG and WTRA reported here are comparable to previously reported rates from these regions of the eastern basin of the Atlantic (Reinthaler et al., 2006; De Corte et al., 2010).

Latitudinal trends of viral abundance and production Generally, the viral abundance was comparable to previous studies conducted in the subtropical Atlantic and Pacific Ocean (Hara et al., 1996; De Corte et al., 2010), but it was one order of magnitude lower than the abundance determined in the eastern basin of the North Atlantic (Parada et al., 2007) using essentially the same enumeration protocol. The VPR increased with depth from $\sim 19$ in the euphotic layer to $\sim 59$ in the bathy- and abyssopelagic waters (Supplementary Table S2, Figure $2 \mathrm{~b}$ ) because of the lower decrease in viral 
abundance with depth as compared with that of prokaryotes. A similar increase in the VPR with depth has been previously described for the eastern basin of the Atlantic (Parada et al., 2007; De Corte et al., 2010) and the Mediterranean Sea (Magagnini et al., 2007).

On a latitudinal scale, the VPR increased in all the depth layers from the ARCT toward the WTRA (Figure 2b). Consequently, the VPR was negatively related to the leucine incorporation rates. With the current knowledge on the ecology of viruses, we cannot fully explain the relatively high abundance of viruses compared with that of prokaryotes in the deep ocean as indicated by the high VPR in the bathypelagic waters reported here and elsewhere (Parada et al., 2007; De Corte et al., 2010). A possible explanation of the high VPR at depth is the longer survival time of phages (that is, lower decay rates) in the deep waters than in the sunlit surface waters where phages remain infective for 1-2 days (Wilhelm et al., 1998). Our findings of increasing VTT with depth (Table 1) together with previously reported VTT in the deep waters of the eastern basin of the North Atlantic of about 40 days (Parada et al., 2007) further support the longer survival time of viruses in deep waters to sustain their relatively higher abundance. Furthermore, the lack of a relation between viral and prokaryotic abundance in the bathy- and abyssopelagic layers (Table 2) might be caused by the allochthonous input of viruses attached to sinking particles derived from surface waters (Parada et al., 2007). Phages embedded in particles might exhibit lower decay rates and consequently longer survival times than freeliving viruses (Kapuscinski and Mitchell, 1980). A predominately non-random distribution of deepwater microbes including viruses might therefore also explain the high VPR in deep waters. Indeed, there is genomic evidence that deep-water bacteria have more genes indicative of a particle-attached life mode than surface water bacteria (DeLong et al., 2006). Riemann and Grossart (2008) determined a high phage production from particle-associated prokaryotes using a model system, supporting our hypothesis that a predominately particle-attached life strategy might sustain a high abundance of viruses in the deep ocean. This assumed predominant particle-attached life style in deep waters is also in agreement with remarkably stable concentrations of suspended, buoyant particles throughout the water column in the open ocean (Baltar et al., 2009; Bochdansky et al., 2010).

The most abundant viral population was the medium-fluorescence population (Supplementary Table S2). This is in agreement with a study conducted in the subtropical Atlantic (De Corte et al., 2010), however, in contrast to coastal environments where the low-fluorescence viral population dominates (Marie et al., 1999; Larsen et al., 2001; Kimmance et al., 2007; Pan et al., 2007). Assuming that the green fluorescence of the viruses stained with SYBR Green is related to the nucleic acid content, it suggests a higher contribution of viruses with a medium nucleic acid content in the open ocean than in coastal environments. However, only limited information is available on the ecology of these viral subgroups. A few studies indicate, however, that the high-fluorescence viral population is frequently associated with viruses infecting eukaryotic plankton (Brussaard et al., 2000; Brussaard, 2004). Thus, further studies are needed to decipher the nature and source of these three viral sub-population in the marine ecosystem.

The lytic VP exponentially decreased with depth (Table 1, Figure 5). Lytic VP was one order of magnitude lower than in a study conducted in the same depth layers of the subtropical Atlantic Ocean (De Corte et al., 2010) and two orders of magnitude lower than in the Southern Ocean (Evans et al., 2009). The lytic VP obtained in our study was, however, one order of magnitude higher than reported for the Mediterranean Sea (Weinbauer et al., 2003). In contrast to the lytic VP, the lysogenic VP did not vary with depth (Table 1). An increasing proportion of lysogeny to total VP was detectable in our study from the ARCT to the WTRA (Table 1). The increasing contribution of lysogeny to total VP with decreasing heterotrophic production along the latitudinal transect is in agreement with the hypothesis of Weinbauer et al. (2003) suggesting that lysogeny as an adaptation to low host abundance and activity.

The bacterial turnover time obtained in the VP assays decreased toward the WTRA while the turnover time of the lytic VP measured in the same experiments did not significantly vary with latitude (Table 1). Thus, a discrepancy between viral and bacterial turnover times was observed in the NAG and WTRA, where the PTT was one order of magnitude lower than the VTT. These results support the hypothesis that oligotrophic conditions, characterized by low phytoplankton and prokaryotic production, favor the lysogenic over the lytic viral cycle (Weinbauer and Suttle, 1999; Williamson et al., 2002; Williamson and Paul, 2004).

\section{Links between viral and environmental variables} The relationships between viral abundance and biotic and abiotic parameters differed among the oceanographic provinces and depth layers (Tables 2 and 3). The heterotrophic prokaryotic production (measured as leucine incorporation) was the main explanatory variable for viral abundance in the epipelagic layer over the entire latitudinal transect, suggesting a tight coupling between prokaryotes and viruses in the sunlit epipelagic waters regardless the oceanographic province (Table 2). Remarkably, latitude alone explained only $5 \%$ of the variability in viral abundance in the epipelagic layer but $43 \%$ and $82 \%$ in the bathy- and abyssopelagic layer, respectively (Table 2). This is counterintuitive because one would generally assume that latitude exerts more 
influence on surface waters with varying trophic conditions than on the bathy- and abyssopelagic realm, which is generally considered more uniform over several oceanographic provinces. This pattern confirms recent evidence that the deep ocean is as dynamic as surface waters (Aristegui et al., 2009).

\section{Conclusion}

Taken together, our data show distinct patterns in prokaryotic abundance and activity along the latitudinal transect from the Arctic to the equatorial province linked to the general thermohaline circulation pattern and water column structure. In the ocean's interior, low heterotrophic prokaryotic activity under the gyre systems coincides with high VPRs. Hence, heterogeneity in the microbiota is not restricted to the euphotic zone, but it is even more pronounced in the meso- to abyssopelagic waters indicating that low epipelagic primary production, characteristic for the gyre systems, coupled with a stratified water column is linked to low heterotrophic prokaryotic activity and high VPRs in the underlying bathy- and abyssopelagic waters.

Consequently, our data suggest that virus-host interactions might drastically change in response to the changes in the biotic and abiotic variables throughout the oceanographic provinces of the North Atlantic. The increasing VPR with depth remains enigmatic, however, and might be related to a predominately particle-attached life mode of deepsea microbes as suggested by metagenomic data and other microbial oceanography studies. Whether or not fragile deep-sea particles are really responsible for the non-random distribution of microbes remains to be resolved, however, requiring new sampling techniques to specifically collect these particles.

\section{Acknowledgements}

We thank the captain and crew of R/V Pelagia for their support and splendid atmosphere on board. ES was supported by the ESF MOCA project and the Austrian Science Fund (FWF) projects: I486-B09 and P23234-B11 to GJH, TY was supported by the Dutch Science Foundation (ALW-NWO project Geotraces), DDC received a fellowship of the University of Groningen. Laboratory work was supported by the Austrian Science Fund (FWF) projects: I486-B09 and P23234-B11 to GJH. This work is in partial fulfillment of the requirements for a $\mathrm{PhD}$ degree from the University of Groningen by DDC.

\section{References}

Anderson MJ, Ford RB, Feary DA, Honeywill C. (2004). Quantitative measures of sedimentation in an estuarine system and its relationship with intertidal softsediment infauna. Mar Ecol Prog Ser 272: 33-48.

Angly FE, Felts B, Breitbart M, Salamon P, Edwards RA, Carlson $\mathrm{C}$ et al. (2006). The marine viromes of four oceanic regions. PLoS Biol 4: e368.
Aristegui J, Gasol JM, Duarte CM, Herndl GJ. (2009). Microbial oceanography of the dark ocean's pelagic realm. Limnol Oceanogr 54: 1501-1529.

Baltar F, Aristegui J, Gasol JM, Sintes E, Herndl GJ. (2009). Evidence of prokaryotic metabolism on suspended particulate organic matter in the dark waters of the subtropical North Atlantic. Limnol Oceanogr 54: 182-193.

Bochdansky AB, van Aken HM, Herndl GJ. (2010). Role of macroscopic particles in deep-sea oxygen consumption. Proc Natl Acad Sci USA 107: 8287-8291.

Bratbak G, Egge JK, Heldal M. (1993). Viral mortality of the marine alga emiliania-huxleyi (haptophyceae) and termination of algal blooms. Mar Ecol Prog Ser 93: 39-48.

Breitbart M, Middelboe M, Rohwer F. (2008). Marine viruses: community dynamics, diversity and impact on microbial processes. In: Kirchmam DL (ed). Microbial Ecology of the Oceans, 2nd edn. John Wiley \& Sons, Inc.: Hoboken, NJ, USA, pp 443-479.

Brussaard CPD. (2004). Optimization of procedures for counting viruses by flow cytometry. Appl Environ Microbiol 70: 1506-1513.

Brussaard CPD, Marie D, Bratbak G. (2000). Flow cytometric detection of viruses. J Virol Methods 85: 175-182.

De Corte D, Sintes E, Winter C, Yokokawa T, Reinthaler T, Herndl GJ. (2010). Links between viral and prokaryotic communities throughout the water column in the (sub)tropical Atlantic Ocean. ISME J 4: 1431-1442.

Del Giorgio P, Bird DF, Prairie YT, Planas D. (1996). Flow cytometric determination of bacterial abundance in lake plankton with the green nucleic acid stain SYTO 13. Limnol Oceanogr 41: 783-789.

DeLong EF, Preston CM, Mincer T, Rich V, Hallam SJ, Frigaard N-U et al. (2006). Community genomics among stratified microbial assemblages in the Ocean's interior. Science 311: 496-503.

Evans C, Pearce I, Brussaard CP. (2009). Viral-mediated lysis of microbes and carbon release in the subAntarctic and Polar Frontal zones of the Australian Southern Ocean. Environ Microbiol 11: 2924-2934.

Hara S, Koike I, Terauchi K, Kamiya H, Tanoue E. (1996). Abundance of viruses in deep oceanic waters. Mar Ecol Progr Ser 145: 269-277.

Kapuscinski RB, Mitchell R. (1980). Processes controlling virus inactivation in coastal waters. Water Res 14: 363-371.

Kimmance SA, Wilson WH, Archer SD. (2007). Modified dilution technique to estimate viral versus grazing mortality of phytoplankton: limitations associated with method sensitivity in natural waters. Aquat Microb Ecol 49: 207-222.

Kirchman DL. (2002). Calculating microbial growth rates from data on production and standing stocks. Mar Ecol Prog Ser 233: 303-306.

Larsen A, Castberg T, Sandaa RA, Brussaard CPD, Egge J, Heldal $M$ et al. (2001). Population dynamics and diversity of phytoplankton, bacteria and viruses in a seawater enclosure. Mar Ecol Prog Ser 221: 47-57.

Longhurst AR. (1998). Ecologycal Geography of the Sea. Academic Press: San Diego, CA, USA.

Magagnini M, Corinaldesi C, Monticelli LS, De Domenico E, Danovaro R. (2007). Viral abundance and distribution in mesopelagic and bathypelagic waters of the Mediterranean Sea. Deep-Sea Res Pt I 54: 1209-1220.

Marie D, Brussaard CPD, Thyrhaug R, Bratbak G, Vaulot D. (1999). Enumeration of marine viruses in culture and 
natural samples by flow cytometry. Appl Environ Microbiol 65: 45-52.

Middelboe M. (2000). Bacterial growth rate and marine virus-host dynamics. Microbial Ecol 40: 114-124.

Middelboe M, Jørgensen NOG. (2006). Viral lysis of bacteria: an important source of dissolved amino acids and cell wall compounds. J Mar Biol Assn UK 86: $605-612$.

Middelboe M, Lyck PG. (2002). Regeneration of dissolved organic matter by viral lysis in marine microbial communities. Aquat Microb Ecol 27: 187-194.

Middelboe M, Riemann L, Steward GF, Hansen V, Nybroe O. (2003). Virus-induced transfer of organic carbon between marine bacteria in a model community. Aquat Microb Ecol 32: 1-10.

Nagata T, Fukuda H, Fukuda R, Koike I. (2000). Bacterioplankton distribution and production in deep Pacific waters: large-scale geographic variations and possible coupling with sinking particle fluxes. Limnol Oceanogr 45: 426-435.

Ortmann AC, Lawrence JE, Suttle CA. (2002). Lysogeny and lytic viral production during a bloom of the Cyanobacterium Synechococcus spp. Microbial Ecol 43: 225-231.

Pan LA, Zhang J, Zhang LH. (2007). Picophytoplankton, nanophytoplankton, heterotrohpic bacteria and viruses in the Changjiang Estuary and adjacent coastal waters. J Plankton Res 29: 187-197.

Parada V, Baudoux AC, Sintes E, Weinbauer MG, Herndl GJ. (2008). Dynamics and diversity of newly produced virioplankton in the North Sea. ISME J 2: 924-936.

Parada V, Sintes E, van Aken HM, Weinbauer MG, Herndl GJ. (2007). Viral abundance, decay, and diversity in the meso- and bathypelagic waters of the North Atlantic. Appl Environ Microbiol 73: 4429-4438.

Pommier T, Canback B, Riemann L, Bostrom KH, Simu K, Lundberg $\mathrm{P}$ et al. (2007). Global patterns of diversity and community structure in marine bacterioplankton. Mol Ecol 16: 867-880.

Pytkowicz RM. (1971). On the apparent oxygen utilization and the preformed phosphate in the oceans. Limnol Oceanogr 16: 39-42.

Reinthaler T, van Aken H, Veth C, Aristegui J, Robinson C, Williams PJLR et al. (2006). Prokaryotic respiration and production in the meso- and bathypelagic realm of the eastern and western North Atlantic basin. Limnol Oceanogr 51: 1262-1273.

Riemann L, Grossart HP. (2008). Elevated lytic phage production as a consequence of particle colonization by a marine Flavobacterium (Cellulophaga sp.). Microbial Ecol 56: 505-512.

Sano E, Carlson S, Wegley L, Rohwer F. (2004). Movement of viruses between biomes. Appl Environ Microbiol 70: 5842-5846.

Sathyendranath S, Longhurst A, Caverhill CM, Platt T. (1995). Regionally and seasonally differentiated primary production in the North Atlantic. Deep-Sea Res Pt I 42: 1773-1802.

Schattenhofer M, Fuchs BM, Amann R, Zubkov MV Tarran GA, Pernthaler J. (2009). Latitudinal distribution of prokaryotic picoplankton populations in the Atlantic Ocean. Environ Microbiol 11: 2078-2093.

Schlitzer R. (2002). Interactive analysis and visualization of geoscience data with Ocean Data View. Comput Geosci 28: 1211-1218.

Smith DC, Azam F. (1992). A simple, economical method for measuring bacterial protein synthesis rates in seawater using 3H-leucine. Mar Microb Food Webs 6: 107-114.

Thingstad TF, Lignell R. (1997). Theoretical models for the control of bacterial growth rate, abundance, diversity and carbon demand. Aquat Microb Ecol 13: 19-27.

Varela MM, van Aken HM, Sintes E, Herndl GJ. (2008). Latitudinal trends of Crenarchaeota and Bacteria in the meso- and bathypelagic water masses of the Eastern North Atlantic. Environ Microbiol 10: 110-124.

Weinbauer MG, Brettar I, Hofle MG. (2003). Lysogeny and virus-induced mortality of bacterioplankton in surface, deep, and anoxic marine waters. Limnol Oceanogr 48: 1457-1465.

Weinbauer MG, Fuks D, Peduzzi P. (1993). Distribution of viruses and dissolved DNA along a coastal trophic gradient in the Northern Adriatic Sea. Appl Environ Microbiol 59: 4074-4082.

Weinbauer MG, Suttle CA. (1999). Lysogeny and prophage induction in coastal and offshore bacterial communities. Aquat Microb Ecol 18: 217-225.

Wilhelm SW, Brigden SM, Suttle CA. (2002). A dilution technique for the direct measurement of viral production: a comparison in stratified and tidally mixed coastal waters. Microbial Ecol 43: 168-173.

Wilhelm SW, Weinbauer MG, Suttle CA, Jeffrey WH. (1998). The role of sunlight in the removal and repair of viruses in the sea. Limnol Oceanogr 43: 586-592.

Williamson SJ, Houchin LA, McDaniel L, Paul JH. (2002). Seasonal variation in lysogeny as depicted by prophage induction in Tampa Bay, Florida. Appl Environ Microbiol 68: 4307-4314.

Williamson SJ, Paul JH. (2004). Nutrient stimulation of lytic phage production in bacterial populations of the Gulf of Mexico. Aquat Microb Ecol 36: 9-17.

Winter C, Smit A, Szoeke-Denes T, Herndl GJ, Weinbauer MG. (2005). Modelling viral impact on bacterioplankton in the North Sea using artificial neural networks. Environ Microbiol 7: 881-893.

This work is licensed under the Creative Commons Attribution-NonCommercial-No Derivative Works 3.0 Unported License. To view a copy of this license, visit http://creativecommons. org/licenses/by-nc-nd/3.0/

Supplementary Information accompanies the paper on The ISME Journal website (http://www.nature.com/ismej) 